\title{
Investigating the Challenges Faced by Kurdish EFL Teachers in Teaching English Listening and Speaking Skills at Public Universities in the Kurdistan Region of Iraq
}

\author{
Rasti Nawzad Ahmed \\ Translation Department, College of Languages, Sulaimani University, Kurdistan Region, Iraq \\ rasti.ahmed@univsul.edu.iq
}

\begin{abstract}
Since English is a global language, learning to speak this language results in better education opportunities and more employment chances. Therefore, Teaching English as a Foreign Language (TEFL) has greatly expanded around the world and it has become a crucial part of the higher education curriculum at the public universities in Kurdistan of Iraq as well. Regardless of the significant advancement in technology and the expansion in teaching strategies, there are still challenges that are faced by EFL teachers when it comes to teaching English. This is especially true for teaching listening and speaking skills, since it requires a supportive context and provided facilities. Hence, this study attempts to investigate the challenges that Kurdish EFL teachers face in teaching English listening and speaking skills at the public universities in Iraqi Kurdistan and suggest some ways in which these can be dealt with. To achieve these aims, I have chosen to conduct this study as a case study in the qualitative paradigm, using a questionnaire for the data collection. The questionnaire was answered by 10 Kurdish EFL teachers who teach English language skills at different public universities across the region. The collected data was analysed in a thematic approach by means of coding. As it appears from the findings, the Kurdish EFL teachers have faced some common challenges, such as: lack of tech-facilities, large- and mixed level classes and limited class time, and have also suggested some ways for dealing with them.
\end{abstract}

Key words: Challenges, listening and speaking skills, Kurdish EFL teachers and public universities. 


\section{Introduction}

It is fair to say that the English language has become one of the most powerful languages throughout the world, which is commonly used among people for various purposes. Nowadays, English is the language for international communication, science, commerce, advertising, diplomacy and transmitting advanced technology and it has become a "lingua franca" among speakers of languages that are not mutually intelligible (Coury \& Carlos, 2001). Also, learning to speak the English language can guarantee the availability of opportunities to employment, traveling, higher education, and even better life (Crystal, 1997). Furthermore, a good English language proficiency is of great importance in conducting research: it helps in searching for academic resources mainly obtainable in English. Therefore, Teaching English has become very popular and it is also regarded as crucial at the academic level. That is why at almost all the public universities in Kurdistan of Iraq, English is taught as a foreign language, especially to first-year students in most departments.

It can be claimed that to communicate effectively, one must have the ability to listen and speak fluently in the desired language. Davies and Pearse (2000, p. 99) state that "Real success in English teaching and learning is when the learners can actually communicate in English inside and outside the classroom". For this to happen, EFL teachers need to teach listening and speaking skills so that the learners develop the skills to listen and speak fluently in English and carry out meaningful conversations. Furthermore, Raimes (1983, cited in Tavil 2010) claims that listening and speaking are at least as important as the other skills to communicate regardless of who the people using the language are. Thus, for a successful EFL teaching experience, it is crucial to regard the importance of teaching listening and speaking skills under well-prepared circumstances and a supportive EFL teaching environment. A supportive EFL teaching environment is suitable for the teaching of language skills, especially listening and speaking. That is; the classroom needs to be organized and equipped in a way that facilitates the teaching of these skills. As it is claimed by Eltaib (2011, cited in Hwaider 2017), the teaching environment must be as suitable as possible for learning in general, and foreign language teaching in particular and there must be special conditions and facilities for supporting the teaching of a foreign language because teaching does involve not only methods and techniques but also sufficient time, class organisation and possibly training.

As with any other vocation, there are various challenges faced by EFL teachers, regardless of what skill they teach. Endriyati (2019) claims that teaching English as a foreign language is a challenging task that requires teachers to pay attention to the language skills of the students such as reading, writing, listening, and speaking. Nonetheless, Anyiendah (2017) claims that the teacher's training and innovative skills are necessaries, but it is not a sufficient condition for effective learning and that there are other prevailing conditions which pose challenges to the teacher hence impede learning. Thus, EFL teachers face various challenges, especially when the teaching environment is not supportive of the teaching process and lacks the necessary facilities. Therefore, it is only fair to say that most EFL teachers encounter difficulties, as the teaching of a language requires more than being able to speak it and that for many of them, these challenges are believed to diminish teaching proficiency.

Hence, the purpose of this study is to investigate the challenges experienced by Kurdish EFL teachers who teach English listening and speaking skills at public universities in Iraqi Kurdistan, because there are more challenges in this regard, due to the fact that teaching these skills demands a supportive context in which facilitation is provided. This study also aims at suggesting some ways in which these challenges can be dealt with, so that the process of TEFL at public universities can be efficiently enhanced. Moreover, it focuses on the challenges faced in teaching listening and speaking skills together instead of focusing on them separately, because they are taught together at most of the departments at the public universities in the region.

\section{Literature Review}

The main focus of this study is to investigate the challenges that Kurdish EFL teachers face in teaching English listening and speaking skills at public universities in Kurdistan of Iraq. Therefore, this section will define both listening and speaking skills and describe their importance in EFL teaching. It will also discuss the most commonly experienced challenges among teachers who teach English listening and speaking skills as a foreign language in terms of relevant literature. 
2.1 The Definition and Importance of Listening and Speaking Skills

\subsubsection{Listening skills}

There are four skills that need to be acquired when learning a new language. These are listening, speaking, reading and writing, which are abilities that allow learners to perceive and generate spoken language to communicate with others correctly and effectively. Purdy (1997, p.8) defines listening as "the active and dynamic process of attending, perceiving, interpreting, remembering, and responding to the expressed (verbal and nonverbal), needs, concerns and information supplied by other human beings". In addition, listening is defined by Rost (2002) as a process of receiving what the speaker actually says (receptive orientation); producing and representing meaning (constructive orientation); negotiating and responding to meaning with the speaker (collaborative orientation); and generating meaning via participation, imagination, and empathy (empathetic orientation) (transformative orientation). Therefore, it can be claimed that listening is a sophisticated, active interpretation process in which listeners not only allow input to be heard, but also try to figure out what they heard; construct, negotiate and generate meaning. Moreover, Kashinathan and Aziz (2021) state that listening is typically the first ability mastered when learning a language, followed by speaking, reading, and finally writing. Hence, it can be said that listening is a primitive language skill that needs to be taught explicitly early on in the process of language teaching.

\subsubsection{Speaking skills}

Language is a tool for communication whereby speakers express, share and exchange ideas with each other. Communication takes place when the speaker has the ability and skills to speak in the desired language. Rickheit and Strohner (2008, p.207) define speaking as "speech or utterances with the purpose of having intention to be recognized by the speaker and the receiver processes the statements in order to recognize their intentions". When one speaks of learning a new language, it is meant that the learner needs to learn about the sound system, language form, vocabulary and grammar of that language. Nevertheless, the main focus needs to be on having the ability to engage in real communication. As Nunan (1999, p.39) argues, the success in learning a language is measured in terms of the ability to carry out a conversation in the (target) language. Since in real life listening and speaking are always in integration, it is believed that the teaching of these two skills should be integrated together in order to facilitate the learners' communicative competence. Moreover, Christopher (2016) claims that listening and speaking are intertwined to the point where one's lack of competency has a direct effect on the other. Therefore, it is crucial that these two skills are taught together successfully by EFL teachers. However, the teaching of these two skills is not easy, especially in contexts that lack the supportive facilities for it. As claimed by Alrawashdeh \& Al-zayed (2017) teachers face different kinds of problems that make the process of teaching listening and speaking slow and rather weak. The next section presents some of the most commonly faced challenges by EFL teachers, teaching listening and speaking skills.

\subsection{Common Challenges Faced by EFL Teachers in Teaching Listening and Speaking Skills}

In teaching English language skills, teachers face various challenges, especially in the countries where English is taught as a foreign language. There are many studies carried out that investigate the challenges faced by EFL teachers in teaching English, among them listening and speaking skills. It can be noted that in most of these studies, there are some prominent challenges that are commonly shared among EFL teachers.

One of the most commonly shared challenges among EFL teachers who teach listening and speaking skills is the issue of largesized classes. According to Blatchford et al. (2002), class size is a very important environmental factor that influences teachers and students in a number of ways. What constitutes as a large class may vary from setting to setting. Jones (2007, p.4) mentions that "in an ideal, students-centered class, the class is made up of 12 students who belong to approximately the same level". However, at public universities in Iraqi Kurdistan, it is common to find classes of up to 30 students, so a class with 35 students or 
more is considered large. Thus, when this is the case, the size of the class creates difficulties for the teacher. Eltaib (2011, cited in Hwaider 2017) mentions that large classes are not suitable for teaching listening and speaking skills, as there will not be sufficient time to allow for fair participation among the students and the teachers' strategies for teaching will not be effective in such an environment. In addition, Hayes (1997) points out the problems with teaching in large classes as follows: discomfort, lack of control, absence of individual attention, insincere evaluation and inefficient learners. He also adds that given that class size is most unlikely to be reduced in the foreseeable future, teachers need to come to terms with their problems.

A further challenge for EFL teachers, that can be linked with the previous one, is the issue of mixed-level classes, where students have different abilities, background knowledge and proficiency. According to Biggs (1999, cited in Aoumeur, 2017), practical problems faced by students and teachers increase and change in their nature as class size increases, especially in tertiary level institutions where the student population is more diverse and the teaching staff have to deal with a variety of factors, such as student ability, background, age and experience. Hence, it is difficult for teachers in such classroom to meet with all of the students' needs equally at the same time, since the students will have different learning needs based on their English language level. Moreover, Bekiryazıcı (2015, p.913) claims that most of the time "teachers may prefer teaching in accordance with the level of upper-middle section, however more advanced students can feel that they do not learn much while students with lowest levels can have difficulty in understanding what is going on in the class". When this is the case, it is very challenging for the teacher to create a balance in the classroom, especially when teaching listening and speaking skills because the teacher needs to find ways to adapt to the listening or speaking tasks continuously in order to be able to deliver a class that meets with the students' needs at every level.

Another common challenge for EFL teachers who teach listening and speaking skills is limited class time. The time devoted to teaching listening and speaking skills should be sufficient to perform individual and group tasks inside the class and enhance exposure time to the language. Maryslessor, Barasa and Omulando (2014) found out that time limitation is regarded as one of the prominent challenges that teachers face in teaching listening and speaking. If the time is limited and the teacher needs to teach a large class, then the students will not have equal participation opportunities, which is a challenge for the teacher to compensate for. Also, Cummins (2006, cited in Anyiedah 2017) postulated that given that language learning requires a lot of exposure, the class time limitation is a challenge for EFL teachers.

Furthermore, it can be said that technology has various advantages in language learning and teaching. Also, in EFL teaching contexts, technology is needed inside the classroom, especially for teaching listening and speaking. Thus, the lack of technological facilities inside classrooms is another challenge for EFL teachers teaching these skills. As it is cited in Kusumaningtyas (2017, p.4) technology facilitates knowledge enrichment in the classroom (Young, 2008), it engages the students' critical thinking and problem- solving, which will increase their motivation in learning English (Costley, 2014) and finally technology devices help students to comprehend the materials efficiently and effectively (Nomass, 2013). Furthermore, technology helps the teacher to bring the learners the feeling of the real world (Cao, 2015). For example, when it is in the listening session, students can hear the native's voice from some computer programs that the teacher uses. Through this way, it will attract students' attention because they are interested in the "real world" learning situation (Zhang \& Zhang, 1994, as cited in Cao, 2015).

Finally, EFL teachers who teach listening and speaking skills face challenges in dealing with students, especially those with low English proficiency and lack motivation to learn. According to Shah, Hussain and Nasseef. (2013, p.108), "In EFL classrooms, dealing efficiently with learners is one of the core factors which challenge teachers' skills and abilities and that learners, who show no interest in classroom activities, usually underperform and underachieve; such learners often lack motivation and resist classroom participation".

Moreover, Finocchiaro \& Brumfit (1983, p.92) and Hasan (1991, p.117) state that students' motivation has great importance in acquiring knowledge and skills and Beare (2009) also claims that the mental barrier is often one of the major obstacles for students in learning any skill (cited in Hwaider, 2017). Students who have low English proficiency and are unconfident about their language skills tend to believe that they lack the ability to understand and interact with the lesson, thus develop a negative 
attitude towards the language, which acts as a barrier in their learning process. This negative attitude emanates from the fact that learners have limited language competence, therefore preventing them from actively participating in classroom activities (Usó Juan, 2006). Hence, Valle (2002, cited in Alrawashdeh1\&Al-zayed, 2017) suggests that EFL teachers should try to create students' interests in learning English through games, songs, stories, and real-life experiences which could furthermore result in greater students' success and enjoyment in studying English.

\section{Methodology}

\subsection{Research Design}

As mentioned earlier, this study investigates the challenges that Kurdish EFL teachers, who teach English listening and speaking skills at public universities face in Iraqi Kurdistan. The study is conducted in the qualitative paradigm. It has applied case study as its strategy, since the focus is on knowing what a specific group of teachers see as challenges in teaching listening and speaking skills, how they describe and interpret their experiences and what they think can be done for dealing with them. According to Swanborn (2010) it is useful to take an intensive approach by applying a case study in research when the researcher is exploring a phenomenon in depth and in its own specific context so as to probe into details he/she is interested in for the purpose of the study.

\subsection{Population and Sampling Technique}

The sample of this study consists of 10 Kurdish EFL teachers who teach or have taught English language as a foreign language, especially listening and speaking skills at public universities across the Kurdistan region of Iraq. They were selected from 6 different public universities in the Kurdistan region of Iraq. Their teaching experience ranges from 5 to 20 years and their age is between 30 and 50 . They consist of both male and female. For the sampling of this study, the non-probability sampling strategy; by means of purposive sampling was applied, in order to study the opinions and experiences of those teachers that were believed will contribute to the answers to the research questions. Dhivyadeepa (2015, p.105) claims that "the main goal of purposive sampling is to focus on a particular characteristic of the population that are of interest, which will best enable the researcher to answer the research questions".

\subsection{Instrumentation}

The instrument used for the data collection in this study is an open-ended questionnaire. In the questionnaire, the participants were asked about what challenges they face in teaching English listening and speaking skills and how they think these can be dealt with. According to Pawar (2004) a questionnaire is a document that contains closed and/or open-ended questions that address the research objectives and questions; it is completed by the participant him/herself and by using questionnaires, researchers can reach a large target group saving on time and pace as well as the data obtained from a questionnaire is easy to analyze and provides quick results. The reason why open-ended questions were used was to reach a wide range of answers without having any influences on the participants' responses. The questions were written in short sentences and a simple language in order to avoid any confusion. As it is stated in Beiske (2002) according to QuickMBA (Questionnaire Design, 2002) the use of open-ended questions in a questionnaire have the advantage of providing the researcher with a wide range of responses that aid in capturing the flavor of participants' answers without influencing the results of the questions by pre-determining possible reactions. The questionnaires were sent by email and the participants were given 2 weeks to answer. 


\subsection{Data Analysis Procedure}

For analysing the data in this study, the thematic approach was applied using coding. The data was closely examined, and the questionnaires' responses were evaluated to identify common themes among them. Ezzy (2002) defines the process of thematic analysis as the coding of theory in which themes or concepts in the data are induced and identified; enabling the researcher to build a systematic account of what he/she has observed and recorded. Furthermore, six steps were followed in analysing the data in a thematic approach developed by Braun and Clarke (2006). The first step was to get familiarized with the data. The second step was coding the data and highlighting repeated similar challenges. The third step was identifying patterns among the data and starting to generate themes: in this case, the most commonly shared challenges amongst the participants. The fourth step was reviewing the themes to ensure that they were useful and accurate and that nothing was missed. The fifth step was defining and naming the themes to represent a different challenge. The final step was to start writing up the data analysis; having the results of the findings address each theme, deciding how often they come up, describing what they mean and including examples from the data as evidence.

\section{Analysis and Discussion of the Results}

This section presents the analysis and discussion of the results of this study, which investigates the challenges that Kurdish EFL teachers face in teaching listening and speaking skills at public universities in Kurdistan of Iraq and the suggested ways for dealing with them. Each of the below presented challenge was decided upon based on the reoccurrence of the same theme, in the thematic analysis. The suggested ways for dealing with the challenges were hinted by the participants for each challenge they mentioned that they had faced. As mentioned earlier, there are 10 participants who took part in this study, each one of them is identified with a letter from the Alpahbet, starting with (A) and ending in (J).

\subsection{Large-Sized Classes}

To begin with, the core challenge shared between the participant of this study is the issue of large-sized classes. The majority of the participants in this study indicate that large-sized classes create serious challenges for them in teaching English listening and speaking skills, since it limits students' opportunity for equal participation, especially during speaking tasks. Participant (A, B, C, D, E, G, H, I and J) believed that large-sized classes are challenging in that it affects the teaching of English listening and speaking and the fact that it impacts the way the teacher can deliver a successful lesson. According to participant (A), the number of the students inside a class has a direct impact on the quality of English language skills' teaching, that is why teaching listening and speaking skills to a large-sized class is a challenge for him/her. He/she has tried to overcome this challenge by following some techniques like: teacher collaboration, integrating Vygotsky's theories to lesson plan and class management and has also suggested implementing co-operative learning techniques among students; that is when students are put in small groups to accomplish a common learning goal under the guidance of the teacher. Furthermore, participant (B) mentioned that large classrooms and lack of time create obstacles in achieving the learning objectives and to address this issue, he/she has tried to create groups, in which he/she has assigned the higher-level students to further explain the lesson to and mentor their classmates while working on the activities. Furthermore, participant $(\mathrm{C})$ and $(\mathrm{J})$ claimed that due to the big number of students inside one classroom, there isn't enough time for students' sufficient involvement in speaking activities. Also, according to participant (D) and (H), the issue of large classes minimalizes equal opportunities for all students to engage in daily participation and that it is difficult for teachers to carry out their lesson plan in an efficient way. All of these points relate to what Eltaib (2011, cited in Hwaider 2017), has mentioned about the inappropriateness of large classes for teaching listening and speaking, as there will not be enough time for fair participation among the students and that teachers' strategies for teaching will not be effective in such an environment. For dealing with these issues created by the size of the class, participant (C) has tried to make time for helping the student, especially those who have weak points, even if it is just a couple of minutes. Participant (D, H and J) all claimed that to overcome these 
issues they have tried the grouping strategy in which they have grouped students together based on their language level and have given them activities accordingly. Participant (J) also said that this gives the teacher the ability to spend some time with each student in the groups. Moreover, participant (E) declared that large-sized classes do in fact pose problems for EFL teachers and to overcome these problems he/she has applied the grouping strategy like participant (D) and (J) and also recommended applying the MALL strategy (Mobile Assisted Language Learning) as a solution. In addition, participant (G) suggested that classes should include less than 20 students for successful language teaching and that departments limit the size of classes based on this. To some extent, this resonated with what Jones $(2007$, p.4) suggests about classroom size by saying that "in an ideal, students-centred class, the class is made up of 12 students". Also, Participant (I) agreed that large classroom size does create a challenge for EFL teachers because it limits students' active participation time, but does not suggest ways in which this can be dealt with. However, participants (F) claimed that it is not the class size that creates a challenge but the limited teaching time and the class's structure; that is how the classroom is arranged and equipped. Thus, it can be said that according to participant (F), the number of students inside each class is not the issue, as long as the classroom is big enough, is equipped with the necessary facilities and that there is enough time for teaching.

\subsection{Mixed-Level Classes}

Secondly, most of the participants believe that the matter of mixed-level classes, in which there is disharmony in students' English language proficiency level and abilities, generates further difficulties for teachers who teach English listening and speaking skills. Participant (A, B, C, D, E, F, G, H and J) stated that the issue of mixed level classes is a challenge for Kurdish EFL teachers who teach at public universities in Iraqi Kurdistan, since not all the students have the same English language proficiency level, thus teaching students with different abilities and language background knowledge creates challenges for them. Participant (A) claimed that mixed-level classes are common at public universities and that this causes anxiety and a boring class environment due to the difference in the students' language proficiency level. To deal with this he/she has tried to adapt to the teaching material according to the different levels of these students, for example: the exercises for an elementary student could be changed into a more advanced and challenging one for higher-level students. Furthermore, according to participant (B), in a mixed-level class, the difficulties arise from students with the lowest level of English proficiency, since they cannot understand, keep up with the course level, and complete the assigned tasks. To deal with them, he/she has put the more advanced students with the lower-level ones in groups so that they can learn from them. Furthermore, participant (D) and (E) mentioned that due to having students with different English language proficiency level and background knowledge inside the same class, it has been difficult for them to teach what they had planned, because it did not suit all of the students' level and needs. These are all in accordance with what Biggs (1999 cited in Aoumeur 2017) mentions, which is the fact that the practical problems faced by students and teachers increase and change in their nature as class size increases, especially in tertiary level institutions where the student population is more diverse and the teaching staff have to deal with a variety of factors, such as student ability, background, age and experience. To deal with this challenge, participant (D) has tried to create a balance in a way that all students feel comfortable and satisfied and none of them feel neglected, but hasn't stated how exactly. Also, participant (E) mentioned that the best way to deal with this challenge is to group students together based on their language level and give them tasks and assignments to complete. Nonetheless, participant (C) declared that most EFL teachers at public universities in Iraqi Kurdistan face this challenge and believes that this is because of the incorrect mechanism used by the ministry of education when admitting students at universities after finishing high school. For him/her the difficulties laid in preparing appropriate material that can fit two, three or even more levels of proficiency at the same time, and also in dealing with the various needs of the students as some wish to participate, some struggle to understand and some get disinterested in the activities because these are above their level or too easy for them to passionately engage with. However, he/she has not provided any suggestions for dealing with these issues. Moreover, participant (F) and (J) claimed that mixed-level classes do pose challenges for EFL teachers at public universities in Iraqi Kurdistan, but they did not mention in which regard. Nevertheless, participant (F) stated that one way to deal with this is to divide students into groups according to an English language proficiency pre-test result. Also, he/she has mentioned another way: starting with a moderate curriculum and increasing the level when the teacher senses that the students respond positively. Moreover, Participant (J) suggested that teachers could group students together based on their abilities and work with them separately, but also mix 
the groups at times so that the students can share their experiences and learn from each other. In addition, Participant (H) said that in mixed-level classes, the challenge for him/her lies in dealing with those students who have understood the lesson the first time and lose interest if the teacher deals with the subject any longer for the sake of the lower-level student. This relates to what Bekiryazıcı (2015) says about teaching mixed-level classes and that the issue is that more advanced students can feel that they do not learn much while students with lowest levels can have difficulty understanding what is going on in the class. Therefore, participant $(\mathrm{H})$ said that he/she had mixed the students in groups and asked the more advanced students to further elaborate on the subject for the lower-level students, so that all the students are involved equally in the lesson. Nevertheless, participant (G) mentioned that this is a challenge for him/her and to deal with it he/she has used a mix of difficult and easy tasks, assignments and evaluation tests with his/her students. However, according to participant (I) this is not a challenge at the public universities in Kurdistan, because most of the students have the same level of English language proficiency, except for a few number of students who are exceptional in terms of their language abilities. This claim was very interesting, since it disagreed with what most of the participants claimed with regard to having disharmonious classes.

\subsection{Limited Class Time}

Another identified challenge in teaching English listening and speaking skills at public universities that is shared among the participants of this study is the issue of limited class time. The majority of the participants believe that the number of hours assigned to teaching English language skills at their departments, which ranges from 3 to 5 hours per week is limited and therefore teachers face difficulties in teaching these skills effectively. Participant (A) claimed that limited class time is a challenge for teachers teaching listening and speaking skills, since it restricts the teacher's ability to give equal participation time to all students. As stated by Maryslessor, Barasa and Omulando (2014) if the time is limited and the teacher needs to teach a large class, the students will not have equal participation opportunities and this creates a challenge for the teacher in compensating for it. Participant (A) also mentioned that this issue is something that teachers can do nothing about, since class time is set by college/ department administrators. Participant (B, D and F) hinted that it is absolutely important to increase the teaching hours for the English language teaching classes, since in most public universities the scheduled hours do not exceed 5 hours per week, and this is not sufficient for teaching listening and speaking skills. Nonetheless, participant (F) said that this challenge can be dealt with by limiting the number of students inside each classroom. Also, participant (B) and $(\mathrm{H})$ stated that increasing assigned tasks and homework to students can to some extent compensate for the class time limitation. Nevertheless, participant (D) did not mention how this problem can be dealt with. Moreover, participant (E) said that limited class hour is a challenge, but it can be compensated for by using online platforms for teaching or giving tasks or homework as workload outside the class. Also, participant (I) claimed that the teaching hours must be increased to deal with this problem, or teachers should be encouraged to use online teaching platforms to compensate for the limited time they spend in the class. Furthermore, participant (J) mentioned that language learning, especially learning listening and speaking skills need a lot of time, thus class time limitation is a challenge, which is in accordance with what Cummins (2006, cited in Anyiedah 2017) states that given that language learning requires a lot of exposure, class time limitation is a challenge for EFL teachers. Therefore, he/she has advised teachers to adapt to the lesson's activities to meet the needs of the students and to be carried out within the allocated time. However, participant (C) declared that limited class time should not create a challenge if students are given workload outside the classroom, thus it gives the students time to work independently. Nevertheless, participant (G) said that he/she did not face this issue as the lectures at his/her department are 4 hours per week, and according to him/her that is enough time to go over all the necessary material for each class. Thus, when the participants were asked about how many teaching hours they think is sufficient for teaching EFL, participant (A, B, D, E, F, H and I) have answered that due to the fact that most of their students' English language proficiency is low, they need a minimum of 7 hours per week for acquiring these two skills. They also mentioned that the range of these scheduled hours can vary depending on different department's requirement for English language proficiency, but they agreed that at English and Translation departments, the hours dedicated to teaching English language skills should not be less than 7.

\subsection{Lack of Technological Facilities}

In addition to the difficulties mentioned above, there is also the commonly shared challenge of the lack of necessary technolog- 
ical facilities at public universities in Kurdistan; such as the absence of language labs, computers, audio player and recorders, sound speakers, projectors and other technological equipment that are required for the teaching of listening and speaking skills in ideal classrooms. The majority of the participants claim that they have faced challenges in this regard. Participant (A) declared that one of the prominent challenges faced in teaching listening and speaking skills is the lack of technological facilities inside classrooms at the public universities, such as the absence of sound speakers, audio players, data show projectors and other facilities, but does not mention how this can be avoided. Participant (B) and (F) claimed that it is crucial that EFL teachers use technology, especially for teaching listening skills and that necessary technological facilities should be provided at public universities, since they allow the teacher to acquaint the students with real authentic English. This is in accordance with what (Cao, 2015) says about technology in helping the teachers to bring the learners the feel of the real world, especially in listening sessions, where students can hear the native's voice from some computer programs that the teacher uses. Participant (B) also claimed that without using technological resources, the only source of English oral input that students are exposed to is that of the teacher, which is not sufficient and sometimes unauthentic and in order to deal with this issue, he/she said that he/she has always given the students extra authentic listening activities to work on at home, so that when the students come back to the class, they can discuss what they had learned. Furthermore, to overcome this challenge participant (F) mentioned to have always brought his/her own necessary devices to the class. Moreover, participant (D, E, H and J) stated that the lack of technological facilities at public universities creates problems for EFL teachers and to deal with this they have brought and used their own devices and were self-equipped. In addition, Participant (D) added that the presence of technological facilities in language classrooms is crucial, since these help the students better understand the material. This relates to what Nomass (2013, cited in Kusumaningtyas (2017) mentions about the fact that technology devices help students to comprehend the materials efficiently and effectively. Moreover, participant (I) said that he/she has faced this challenge, but said that he/she has sometimes skipped those parts of the lesson which were impossible to be covered without technological aids. Nevertheless, Participant (C) and (G) claimed that they have not faced this problem as technological facilities were available at their universities.

\subsection{Students' Low Proficiency and Lack of Motivation}

Another difficulty that many of the participants of this study share in teaching English listening and speaking skills at public universities is dealing with students who have a low English language proficiency and a negative attitude towards English, thus show lack of interest and enthusiasm for learning listening and speaking skills. Participants (B, C, D, E, F, G, H, I and J) declared that they have faced challenges in teaching listening and speaking skills to those students who are uninterested and demotivated to learn. They have related this to the fact many of the students have a low English language proficiency level, thus lack the enthusiasm to actively engage in the classroom. This in turn relates to what Usó Juan (2006) says about the impact of students' negative attitude on their active participation and engagement, resulting from their limited competence in English. Also, the participants claimed that for a successful and effective English language learning experience, students need to be willing and motivated to learn, otherwise they will not benefit from the teachers' efforts. This is in accordance with what Beare (2009, cited in Hwaider, 2017) states about the effect of the mental barrier which is often one of the major obstacles for students in learning any skill. Furthermore, the majority of the participants (B, D, E, F, G, H and J) have agreed that one effective way to overcome this issue, is to have students take an English language proficiency evaluation test before their admission to the departments where English language is required, especially at English and Translation departments, thus be enrolled based on an achieved required level, preferably that of an intermediate level. Nonetheless, in case this solution is not applicable for any reason, the participants have suggested other ways in which the teachers can compensate for and overcome this challenge. Participant (B) and (D) said that sometimes this challenge can also be due to the fact that many students do not see the importance of learning the English language and to deal with this they suggest to encourage the students and help them understand the importance of the English language in their future life and career. Also, to overcome this challenge, participant (E) has hinted that teachers should create a safe learning environment where students get the sense of belonging and support. Nonetheless, participant (F) and (G) mentioned that what could also be effective in dealing with this challenge is to choose relevant interesting topics and fun activities for teaching the students these skills in the English, so that they get interested and motivated in learning them. This is also stated by Valle (2002, cited in Alrawashdeh1\&Al-zayed, 2017); suggesting that EFL teachers should try to create students' interests in learning English through the use of games, songs, stories and real-life experiences, which could furthermore result in greater students' success and enjoyment in studying English. Also, participant (C) said that it is a good idea to encourage the students 
through making the class communicative and friendly. In addition, participant (H) and (I) claimed that teachers should always motivate their students to learn English, especially listening and speaking skills by using creative ways, because if they are motivated, the teacher will achieve better results. This is in accordance with what Hasan (1991, p.117, cited in Hwaider, 2017) claims saying that "students' motivation has great importance in acquiring knowledge and skills". Also, participant (J) acknowledged the importance of motivation in learning and thinks that teachers should always support their students and get them involved in the lesson as much as possible. However, participant (A) claimed to not have faced this issue yet, but if so he/she thinks that it will help to give the students positive reinforcement for their efforts and make the class a friendly environment.

\section{Conclusion}

This study has attempted to investigate and illustrate the challenges faced by Kurdish EFL teachers teaching listening and speaking skills at public universities in Kurdistan of Iraq. As it appears from the findings there are five prominent challenges that are commonly shared among the participants of this study, which are with regard to: classroom size, mixed-level classes, limited class time, lack of necessary technological facilities and students' low proficiency and lack of motivation. To a great extent, these challenges can be generalized to all the public universities in Kurdistan of Iraq, since these are commonly shared among the participants of this study, who are all EFL teachers at different departments of different public universities across the region. When teachers are faced with these challenges, the teaching of listening and speaking skills is believed to be hindered and sometimes ineffective. Therefore, it is necessary that these challenges are dealt with efficiently at the public universities in the Iraqi Kurdistan and that supportive environments are provided for the teaching of language skills, especially listening and speaking, since these are the fundamental skills to be learned in any language. Based on what the participants have suggested, these challenges can be dealt with if the followings are implemented either by university, college or department administrators and or EFL teachers in their classrooms:

In order to deal with the challenge of large sized classes, it is strongly advised that university, college and department administrators should work together to set up an enrolment system that will limit the number of students inside EFL classrooms.

Also, the Cooperative learning strategies are recommended to be applied by EFL teachers; that is when students are put in small groups to accomplish a common learning goal under the guidance of the teacher.

Moreover, grouping students together based on their language level and giving them activities accordingly is another suggested way, which is believed to be effective in dealing with this the issue of large classes, since this is believed to allow the students to all participate effectively in the lesson and also have the teacher spend more time with each group.

To deal with the issue of mixed-level class, it has been suggested that English speaking departments set an English language proficiency pre-test as a requisite for enrollment, with a certain required level for students' admission into the department. This is believed to overcome the issue of mixed level classes but also limit the number of students admitted to each department, thus have smaller classes.

It is also hinted that EFL teachers could adapt to the teaching material according to the level of the student, making some activities easy and some more difficult, in order to engage all students based on their level. Furthermore, applying the grouping strategy has been suggested, which is believed to allow students to work on tasks based on their level and learn from each other when grouped with more capable students.

To deal with the issue of limited class time, it is advised by most of the participants that department administrators (depending om their departments' needs) should increase the EFL class time to at least 7 hours per week.

Moreover, EFL teachers are encouraged to give students more workload outside the class to compensate for the limited time they spend inside the class and if possible adapt to the teaching material so that it can be efficiently covered within the allocated time, but most importantly it is suggested that EFL teacher make use of the online teaching platforms for dealing with this issue. 
The challenge of the lack of necessary technological facilities inside EFL classrooms is one that the college and department administrators are held responsible for and should work on providing them, however for dealing with this, the participants have suggested that teachers can be self-equipped, which is not practicable always, or give the students extra listening activities as homework.

To deal with the challenge of students' low English language proficiency and the lack of motivation, it is believed that by applying English proficiency pre-test and demanding a certain required level for students' admission, departments can overcome this issue.

Nonetheless, it is believed that EFL teachers can also deal with this challenge by creating a safe learning environment in which interesting relevant topics and fun activities are used in the teaching process, which is thought to boost motivation and result in better learning. Also, through explaining and showing the importance of the English language in the students' future life and career, teachers can motivate the students to work harder and try to learn and perform better.

Finally, it can be said that there are some prominent commonly shared challenges among Kurdish EFL teachers who teach listening and speaking skills at public universities in the Kurdistan region of Iraq and it is pivotal that these challenges are dealt with efficiently so that teaching and learning can happen effectively.

References

Alrawashdeh, A. I \& Al-Zayed, N. N. (2017). 'Difficulties That English Teachers Encounter while Teaching Listening Comprehension and Their Attitudes towards Them, Canadian Center of Science and Education, English Language Teaching, 10 (5) [Online]. Available at: https://files.eric.ed.gov/fulltext/EJ1140047.pdf (Accessed 21-09-2021)

Anyiendah, M. (2017) 'Challenges Faced by Teachers When Teaching English in Public Primary Schools in Kenya', Frontiers in Education, 2 (13) [Online]. Available at: https://www.researchgate.net/publication/316744102_Challenges_Faced_by_Teachers_When_Teaching_English_in_Public_Primary_Schools_in_Kenya (Accessed 1-08-2021)

Aoumeur, H. (2017) 'The Impact of Class Size on Teaching and Learning English as a Foreign Language: The Case of the Department of English at Abdelhamid Ibn Badis University', Arab World English Journal (AWEJ), 8 (2) [Online]. Available at: https:// dx.doi.org/10.24093/awej/vol8no2.25 (Accessed 10-09-2021)

Beiske, B. (2002) 'Research Methods: Uses and Limitations of Questionnaires, Interviews, and case studies: Scholarly Paper', GRIN Verlag [Online]. Available at: http://www.grin.com/en/e-book/15458/research-methods-uses-and-limitations-of-questionnaires-interviews-and (Accessed 18-08- 2021)

Bekiryazici, M. (2015) 'Teaching Mixed-Level Classes with A Vygotskian Perspective', Elsevier Ltd: Procedia Social and Behavioural Sciences, 186, p913 - 917 [Online]. Available at: https://www.researchgate.net/publication/277971290_Teaching Mixed-Level_Classes_with_a_Vygotskian_Perspective (Accessed 01-09-2021)

Blatchford, P., Moriarty, V., Edmonds, S., \& Martin, C. (2002). 'Relationships between Class Size and Teaching: A Multimethod Analysis of English Infant Schools', American Educational Research Journal, 39(1), p101-132. [Online]. Available at: https:// journals.sagepub.com/doi/10.3102/00028312039001101 (Accessed 05-08-2021)

Braun, V. \& Clarke, V. (2006) 'Using Thematic Analysis in Psychology', Taylor\& Francis Online: Qualitative Research in Psychology, 3(2) [Online]. Available at: https://www.tandfonline.com/toc/uqrp20/3/2 (Accessed 03-08-2021)

Cao, A.P. (2015). 'The application of information technology in China's classroom teaching', Cross-Cultural Communication, 11(5), p61-64 [Online]. Available at: http://www.flr-journal.org/index.php/ccc/article/view/7012/7365 (Accessed 25-08-2021) 
Christopher, A. A. (2016). 'Overcoming Impediments to Learning the Four Language Skills Using Note Books', Advances in Language and Literary Studies, 7(1), p161-167 [Online] Available at: https://files.eric.ed.gov/fulltext/EJ1127531.pdf (Accessed 1-08-2021)

Coury, G. \& Carlos, S. (2001). 'English as a Lingua Franca in the Brazilian Academic World', Karen's Linguistics Issues. [Online] Available at: http://www3.telus.net/linguisticsissues/linguafranca.htm (Accessed on 01-08- 2021)

Crystal, D. (1997). English as a Global Language. Cambridge: Cambridge University Press.

Davies, P. \& Pears, E. (2000) Success in English Teaching. Oxford: Oxford University press.

Dhivyadeepa, E. (2015) Sampling Techniques in Educational Research. USA: Raleigh: Lulu publications.

Endriyati, Prabowo, Abasa \& Akmal (2019). 'Challenges in Teaching English At Rural and Urban Schools and Their Solutions', International Journal of Scientific \& Technology Research, 8(10) [Online]. Available at: https://www.ijstr.org/final-print/ oct2019/Challenges-In-Teaching-English-At-Rural-And-Urban-Schools-And-Their-Solutions.pdf (Accessed 1-08-2021)

Ezzy, D. (2002). Qualitative Analysis: Practice and innovation. London: Routledge.

Hayes, D. (1997) 'Helping Teachers to Cope with Large Classes', Oxford Press: ELT Journal, 51(2) [Online]. Available at: https://www.researchgate.net/profile/David-Hayes3/publication/240584144_Helping_teachers_to_cope_with_large_classes/ links/5963e604aca2728c11274102/Helping-teachers-to-cope-with-large-classes.pdf （Accessed 01-08-2021)

Hwaider, Sh. M. (2017) 'Problems of Teaching the Listening Skill to Yemeni EFL Learners', International Journal of Scientific and Research Publications, 7(6) [Online]. Available at: https://www.researchgate.net/publication/331829390_Problems_of_teaching_the_listening_skill_to_Yemeni_EFL_learners (Accessed 15-08-2021)

Jones, L. (2007) Student-centred classroom. Cambridge: Cambridge University Press.】

Kashinathan, S., \& Aziz, A. A. (2021) 'ESL Learners' Challenges in Speaking English in Malaysian Classroom', International Journal of Academic Research in Progressive Education and Development, 10(2), p983-991 [Online]. Available at: https://hrmars. com/papers_submitted/10355/esl-learners-challenges-in-speaking-english-in-malaysian-classroom.pdf (Accessed 20-08-2021)

Kusumaningtyas, M. I. P. (2017) 'The Resistance of Utilizing Technology in EFL Classrooms: Teachers' Voices', Program Studi Pendidikan Bahasa Inggris FBS-UKSW [Online]. Available at: https://repository.uksw.edu/handle/123456789/14487 (Accessed 12-09-2021)

Maryslessor, A. O., Barasa, P.L. and Omulando, C.A. (2014) 'Challenges Teachers Face in the Use of the Communicative Language Teaching Approach in the Teaching Listening and Speaking Lessons in Lugrari District, Kenya', International Journal of Science and Research (IJSR), 3(9), p83-92 [Online]. Available at: https://www.ijsr.net/archive/v3i9/MDIwMTU0Mzk=.pdf. (Accessed 08-09-2021)

Nunan, D. (1999) Second Language Teaching and Learning. Boston: Heinle \& Heinle Publishers.

Pawar, M. (2004) 'Data Collecting Methods and Strategies' in Pawar, M. (Ed.) Data Colleting Methods and Experiences: A Guide for Social Researchers. Elgin: New Dawn Press Group

Purdy, M. (1997) 'What is listening?' in M. Purdy \& D. Borisoff (Eds.) Listening in everyday life: A personal and professional approach. 2nd ed. Lanham, MD: University Press of America. 
Rickheit, G.\& Strohner, H. (2008) Handbook of Communication Competence. Berlin: De Gruyter Mouton

Rost, M. (2002) Teaching and Researching Listening. London, UK: Longman.

Shah, S. R., Hussain, M. A. \& Nasseef, O. A. (2013) 'Factors Impacting EFL Teaching: An Exploratory Study in the Saudi Arabian Context', Arab World English Journal (AWEJ) 4(3) p104-123 [Online]. Available at: https://awej.org/images/AllIssues/Volume4/ Volume4Number3Sept2013/9.pdf(Accessed 20-08-2021)

Swanborn, P. G. (2010) Case Study Research: What, Why and How? London: SAGE Publications, Ltd.

Tavil, Z. M. (2010) 'Integrating Listening and Speaking to Facilitate English Language Learners' Communicative Competence', Elsevier Ltd: Procedia Social and Behavioural Sciences, 9 [Online]. Available at: https://www.researchgate.net/publication/241123097_Integrating_listening_and_speaking_skills_to_facilitate_English_language_learners\%27_communicative_competence (Accessed 20-08-2021)

Usó Juan, E. (2006) Current Trends in the Development and Teaching of the Four Language Skills. Berlin: M. de Gruyter. 